\title{
Features of the recovery of entrepreneurial activity in Russia in the context of sustainable economic development
}

\author{
Irina Korchagina* \\ Kemerovo State University, Institute of Economics and Management, 650056 Krasnaja ulica 6, \\ Russia
}

\begin{abstract}
The author considers the restoration of entrepreneurial activity in the Russian economy as a factor of sustainable development. We consider data from August 2020 to August 2021 on the number of small and medium-sized enterprises and the number of their employees. Methods of correlation analysis, construction of regression equations, Durbin Watson test, Goldfeld - Quantum test for heteroscedasticity were used. The number of small and medium-sized enterprises in Russia has recovered to the level of August 2020, but this is explained by the regional peculiarities of entrepreneurial activity and the lifting of the moratorium on bankruptcy. Among small and medium-sized enterprises, there were many "zombie companies" that were not officially liquidated until June-July 2021. This also explains the lack of correlation between the number of small and medium-sized enterprises and the average number of employees. The number of personnel in small business is monotonously decreasing; it does not fulfill its function of creating jobs. In addition, in most federal districts of Russia, the number of small and medium-sized enterprises has decreased in absolute terms; almost all of the growth is concentrated in the Moscow agglomeration (Moscow and the Moscow region). In most federal districts, entrepreneurial activity is below the pre-crisis level. This is explained not only by restrictions and bans on the operation of small and medium-sized enterprises during the pandemic, but also by the economic situation in Russia, and a decrease in real incomes of the population. There is no correlation between entrepreneurial activity and inflation indices, but this may also be a consequence of accounting for non-performing firms.
\end{abstract}

\section{Introduction}

An important aspect of sustainable development of the national and regional economy is a high level of entrepreneurial activity [1,2]. Small and medium-sized businesses are essential to achieving the UN's sustainable development goals, including job creation, fostering innovation, and sustainable tourism. The task of increasing the total number of micro, small and medium enterprises is also important [3]. At the same time, the interaction of entrepreneurship and sustainable development, as shown in the review [4], has been

${ }^{*}$ Corresponding author: korchagina-i@mail.ru 
rather unevenly studied in the scientific literature. The best researched business models, competencies, strategies focused on sustainable development of entrepreneurship.

The processes of how small and medium-sized enterprises contribute to sustainable development are much less researched. Small and medium-sized businesses can make a limited contribution to achieving sustainable development goals due to a lack of resources and competencies [5]. Changing the situation usually requires non-standard networking practices of small and medium-sized enterprises, competencies in the sustainable use of local resources available, for example, in ecological settlements of local communities [6]. At the same time, the possibilities of using such non-standard work formats are severely limited.

Therefore, at the moment, the main contribution of small and medium-sized businesses to sustainable development is the reduction of unemployment and poverty, elimination of the shortage of goods and services, damping of economic crises [7], while respecting social and environmental obligations [8]. At the same time, these opportunities in 2020-2021 significantly reduced the coronavirus economic crisis. The recovery of entrepreneurial activity is a significant problem for both developed and developing countries. Small and medium-sized enterprises have a lower margin of safety than large ones. Therefore, they turned out to be the most vulnerable in the situation of the spread of the new coronavirus infection COVID-19 and the resulting global crisis $[9,10]$.

The processes of restoring entrepreneurial activity in 2021, after the lifting of most of the prohibitions and restrictions around the world, are uneven. For example, in the 50 most populated US metropolitan areas, the dynamics of the number of small and medium-sized enterprises in 2020-2021 differed significantly [11]. Some studies demonstrate the impact of certain competencies and work practices on the ability of small and medium-sized firms to recover [12, 13]. However, the impact of COVID-19 on small and medium-sized enterprises has not been sufficiently studied and is one of the most relevant areas of entrepreneurship research [14].

The specifics of the recovery of entrepreneurial activity in Russia have not yet been analyzed in detail in Russian and international studies. However, this is an important aspect of sustainable development of the national economy. Given the large spatial heterogeneity of the country, it is also necessary to analyze the regional aspect of the problem. Therefore, the purpose of the article is to assess the level of recovery of entrepreneurial activity in Russia and its federal districts in 2020-2021.Affiliations of authors should be typed in 9point Times. They should be preceded by a numerical superscript corresponding to the same superscript after the name of the author concerned. Please ensure that affiliations are as full and complete as possible and include the country.

\section{Research methodologies}

The study examines data on the number of small and medium-sized enterprises, the average number of employees in them in Russia as a whole and separately for its federal districts in the period from August 2020 to August 2021.This is explained by the fact that it was in August 2020 that the minimum value of the number of small and medium-sized enterprises.

Monthly and quarterly dynamics are considered, for federal districts - annual data. The observation period of 13 months gives sufficient grounds to draw conclusions about the dynamics of the recovery of entrepreneurial activity. Also, as a control data, a comparison was made with August 2019.

The quantitative data for the analysis were obtained from the Unified Register of Small and Medium Enterprises, which is maintained by the Federal Tax Service of the Russian Federation. Inflation indices were obtained from the official website of the Federal State 
Statistics Service of Russia. The data were processed using standard dynamic analysis techniques, time series analysis, and trend analysis.

\section{Research results}

Table 1 presents the series of dynamics characterizing the number of small and mediumsized enterprises in Russia during the period from August 2020 to August 2021, as well as in comparison with August 2019.The data are presented on the 10th day of each month.

Table 1. Dynamics of the number of small and medium-sized enterprises in Russia in August 2019 and from August 2020 to August 2021.

\begin{tabular}{|c|c|c|}
\hline & $\begin{array}{c}\text { Number of small and medium- } \\
\text { sized enterprises, thousand }\end{array}$ & $\begin{array}{c}\text { Growth rate in relation to the } \\
\text { previous month, percent }\end{array}$ \\
\hline August 2019 & 5836.9 & -7.62 \\
\hline August 2020 & 5590.1 & 0.23 \\
\hline September 2020 & 5602.7 & 0.29 \\
\hline October 2020 & 5619.5 & 0.91 \\
\hline November 2020 & 5670.9 & 0.55 \\
\hline December 2020 & 5702.2 & -0.31 \\
\hline January 2021 & 5684.6 & 0.07 \\
\hline February 2021 & 5688.3 & 0.44 \\
\hline March 2021 & 5713.6 & 1.17 \\
\hline April 2021 & 5780.6 & 0.86 \\
\hline May 2021 & 5830.3 & 0.70 \\
\hline June 2021 & 5871.4 & -4.22 \\
\hline July 2021 & 5623.6 & -0.05 \\
\hline August 2021 & 5621.0 & 0.55 \\
\hline Total increase, & & \\
decrease in 2020- & 31.0 & \\
\hline
\end{tabular}

The data in Table 1 show that by June 2021 the number of small and medium-sized enterprises in Russia had practically recovered to normal values for the economy. It reached approximately 5871 thousand units, which is $0.6 \%$ higher than the level of August 2019. During this period, it was possible to state that the general level of entrepreneurial activity (assessed by the number of small and medium-sized enterprises) returned to the pre-crisis level.

However, all the positive effect was lost in June-July 2021, when the number of small and medium-sized enterprises decreased by 250 thousand. The level of entrepreneurial activity has returned to its lowest levels since the onset of the coronavirus crisis. In general, 
from August 2020 to August 2021, the growth of entrepreneurial activity turned out to be insignificant as a result.

Let us consider further the main statistical estimates of a number of dynamics presented in Table 1. Checking the presence of autocorrelation by the Durbin - Watson test showed that there is an autocorrelation of residuals at a 5\% significance level: the actual value of the criterion was 1.05 with a critical interval of 1.08-1.36.

The dynamics of changes in the number of small and medium-sized enterprises cannot be described by an autoregressive model; therefore, a certain external shock influenced the process under study. The Goldfeld-Quantum test for heteroscedasticity also showed that the assessment of the dynamics of the number of small and medium-sized enterprises and forecasting cannot be performed only on the basis of time series data (F-statistic was 50.63 with a critical value of more than 7.71).

At the same time, although the linear trend equation obtained from the data in Table 1 is unsuitable for forecasting in general, its coefficient $b$ is statistically significant according to the Student's test (the observed value of the criterion is 117.64 with the critical value over 2.59). It amounted to 10.78 , therefore, during the month the number of small and mediumsized enterprises in Russia increased by 10.78 thousand.

However, the dynamics of the indicator under study is better described by a secondorder polynomial (parabola) $y=-3.51 t^{2}+59.95 t+5493.85$. The approximation error is $0.82 \%$, Theil's mismatch coefficient is close to zero, and the determination index is $48.98 \%$. The trend equation and its coefficients are statistically significant according to Fisher's and Student's criteria. Consequently, the processes of recovery of entrepreneurial activity were characterized by peaks in February-April 2021, which were then replaced by lows in JuneJuly 2021.

Let us further consider a time series describing the average number of employees in small and medium-sized enterprises (Table 2).

The data in Table 2 show that the number of employees and the number of jobs did not recover in any way after the crisis. The average headcount of small and medium-sized enterprises has been decreasing every month. In general, from August 2020 to August 2021, more than 870 thousand jobs, or more than $5.5 \%$, were lost in the sphere of small and medium-sized businesses in Russia. This is a significant figure indicating a systemic crisis. Even a slight increase in the number of entrepreneurs did not lead to an increase in the number of jobs. The specifics of the current crisis are such that, due to restrictions and prohibitions on work, small and medium-sized businesses cannot fulfill their traditional function of creating new jobs.

It should be noted that the dynamics of the number of small and medium-sized enterprises did not correlate with the average headcount. The correlation coefficient was 0.2414 , while the critical value at the $5 \%$ significance level with 11 degrees of freedom is 0.5529 . Even a slight recovery in entrepreneurial activity had little or no effect on job creation.

Consider the statistical indicators characterizing the dynamics of the average number of personnel in small and medium-sized enterprises. In the dynamics of this indicator, in contrast to the previous one, autocorrelation is observed. The actual value of the DurbinWatson test is 0.86 , while the critical interval at the 5\% significance level is $1.08-1.36$. Hence, autocorrelation takes place. The dynamics of the number of people employed in small and medium-sized businesses developed in accordance with internal impulses.

Unlike the total number of small and medium-sized enterprises, employment in small and medium-sized enterprises was more dependent not on an external shock, but on internal trends. Checking the presence of heteroscedasticity according to the Goldfeld - Quantum test at the same time shows that it is quite pronounced (F-statistic is 374.61 with a critical value of 7.71). 
Table 2. Dynamics of the number of small and medium-sized enterprises in Russia in August 2019 and from August 2020 to August 2021.

\begin{tabular}{|c|c|c|}
\hline & $\begin{array}{c}\text { Number of small and medium- } \\
\text { sized enterprises, thousand }\end{array}$ & $\begin{array}{c}\text { Growth rate in relation to the } \\
\text { previous month, percent }\end{array}$ \\
\hline August 2019 & 15391.1 & - \\
\hline August 2020 & 15520.0 & 1.63 \\
\hline September 2020 & 15515.1 & -0.04 \\
\hline October 2020 & 15492.8 & -0.14 \\
\hline November 2020 & 15516.2 & -0.15 \\
\hline December 2020 & 15509.8 & -0.04 \\
\hline January 2021 & 15491.1 & -0.12 \\
\hline February 2021 & 15476.7 & -0.09 \\
\hline March 2021 & 15458.6 & -0.12 \\
\hline April 2021 & 15438.4 & -0.13 \\
\hline May 2021 & 15416.4 & -0.14 \\
\hline June 2021 & 15399.2 & -0.11 \\
\hline July 2021 & 14654.7 & -4.83 \\
\hline August 2021 & 14646.5 & -0.06 \\
\hline $\begin{array}{c}\text { Total increase, } \\
\text { decrease in 2020- } \\
2021 \\
\end{array}$ & -873.5 & -5.62 \\
\hline
\end{tabular}

This makes it difficult to build a linear regression model, although it would still show a downtrend. The dynamics of the indicator of the average number of employees in small and medium-sized enterprises cannot be adequately characterized by any known types of regression (polynomial, logarithmic, exponential, etc.). Nevertheless, the decline in the number of people employed in small and medium-sized businesses is obvious.

Thus, the recovery of entrepreneurial activity in Russia was observed until the summer, but then it was interrupted, which emphasizes the trend equation with an inflection point showing a radical change in the trend. It is impossible to find a trend equation for the dynamics of the number of employed in small and medium-sized businesses (either statistical insignificance, or heteroscedasticity, or a high approximation error appears), but this indicator has monotonically and significantly decreased. There is no statistical relationship between the dynamics of the number of small and medium-sized enterprises.

\section{The discussion of the results}

The results obtained can have several explanations. First, the change in the positive trend of the recovery of entrepreneurial activity and its sharp drop in the summer of 2021 may be 
due to regional characteristics. In a number of regions of Russia, during this period, quite strict restrictions on the activities of small and medium-sized enterprises were restored, comparable to the second lockdown (Moscow, Moscow region, St. Petersburg).

In other regions, the authorities limited themselves to more lenient measures (for example, hotels and restaurants were not closed at all, but they were not allowed to work at night from 2.00 to $6.00 \mathrm{AM}$ ). To test this assumption, let us consider the data for the federal districts of Russia, as well as for individual regions, which account for a significant part of small and medium-sized enterprises (Table 3).

Table 3. Dynamics of the number of small and medium-sized enterprises in Russia in August 2019 and from August 2020 to August 2021.

\begin{tabular}{|c|c|c|c|c|}
\hline & \multicolumn{2}{|c|}{$\begin{array}{c}\text { Number of small and medium- } \\
\text { sized enterprises, thousand }\end{array}$} & $\begin{array}{c}\text { Absolute increase or } \\
\text { decrease, thousand }\end{array}$ & $\begin{array}{c}\text { Growth rate, } \\
\text { percent }\end{array}$ \\
\cline { 2 - 3 } & August 2020 & August 2021 & & \\
\hline Russia as a whole & 5590.1 & 5621.0 & 30.9 & 0.55 \\
\hline $\begin{array}{c}\text { Central Federal } \\
\text { District }\end{array}$ & 1706.9 & 1761.9 & 55.0 & 3.22 \\
\hline $\begin{array}{c}\text { Northwestern } \\
\text { Federal District }\end{array}$ & 649.3 & 650.4 & 1.1 & 0.17 \\
\hline $\begin{array}{c}\text { North Caucasian } \\
\text { Federal District }\end{array}$ & 190.9 & 191.2 & 0.3 & 0.16 \\
\hline $\begin{array}{c}\text { Southern Federal } \\
\text { District }\end{array}$ & 666.8 & 660.6 & -6.2 & -0.93 \\
\hline $\begin{array}{c}\text { Volga Federal } \\
\text { District }\end{array}$ & 1000.1 & 994.8 & -5.3 & -0.53 \\
\hline $\begin{array}{c}\text { Ural federal } \\
\text { district }\end{array}$ & 481.6 & 476.8 & -4.8 & -1.00 \\
\hline $\begin{array}{c}\text { Siberian Federal } \\
\text { District }\end{array}$ & 596.0 & 589.2 & -6.8 & -1.14 \\
\hline $\begin{array}{c}\text { Far Eastern } \\
\text { Federal District }\end{array}$ & 298.5 & 296.1 & -2.4 & -0.80 \\
\hline Moscow & 681.4 & 728.8 & 47.4 & 6.96 \\
\hline Moscow region & 339.4 & 363.3 & 23.9 & 7.04 \\
\hline St. Petersburg & 333.2 & 337.6 & 4.4 & 1.32 \\
\hline
\end{tabular}

The data in Table 3 do not allow us to talk about the radical impact of new restrictions and bans on business activities in order to slow down the spread of coronavirus infection. The high potential, large scale, and adaptive capabilities of the Moscow agglomeration (Moscow and the Moscow region, which are closely linked economically) and, to a lesser extent, St. Petersburg mitigated the effect of restrictions and bans on the activities of public catering, the hospitality and entertainment industry.

In the Moscow agglomeration, the total number of small and medium-sized enterprises increased by 71.3 thousand, or a total of $6.98 \%$. It seems that there are quite a few entrepreneurs among them who are actively developing the types of activities that are widespread in the context of a pandemic of a new coronavirus infection (information technology, paid medical services, various delivery services, etc.). The number of small and medium-sized enterprises also increased in St. Petersburg.

In general, entrepreneurial activity has recovered and exceeded the pre-crisis level only in the Central Federal District of Russia (mainly due to the Moscow agglomeration). In the 
Northwestern Federal District and the North Caucasian Federal District, the number of small and medium-sized enterprises in August 2021 compared to August last year did not change significantly (an increase of $0.1-0.2 \%$ ). In the rest of the federal districts, entrepreneurial activity turned out to be below the pre-crisis level. The crisis has caused the greatest damage to small and medium-sized businesses in the Siberian Federal District (the number of small and medium-sized enterprises decreased by $1.14 \%$ ).

For example, in the Kemerovo Oblast - Kuzbass, the restrictions on business operations introduced in the summer of 2021 were rather nominal in comparison with Moscow and, especially, St. Petersburg. They boiled down to the fact that food courts in shopping and entertainment centers could only work for takeaway, catering establishments were to close from 2.00 to 6.00 , events with more than 50 participants in closed rooms were canceled, the occupancy rate of theaters and cinemas should not exceed $50 \%$... However, at the same time, the total number of small and medium-sized enterprises in the region fell by 2.3 thousand or $3.4 \%$. Consequently, the varying degrees of coronavirus restrictions had less impact on the recovery of entrepreneurial activity in Russia. A large asymmetry in the levels of economic development of the Moscow agglomeration and other regions affected.

Since entrepreneurial activity in most regions has not recovered to the pre-crisis level even after the restrictions were almost completely lifted, we can talk about another factor the lack of market power in small and medium-sized businesses amid inflation. During the crisis, the world economy faced high rates of price growth; in the Russian economy, these processes were aggravated by the effect of the exchange rate pass-through in prices. However, prices rise unevenly depending on the level of market power of firms and the degree of elasticity of demand. Small and medium-sized businesses often fall into the "price scissors" when the cost of purchases rises and consumer demise falls (since the real incomes of the population are declining).

The study investigated the relationship between inflation indices and the number of small and medium-sized enterprises, as well as the number of people employed in small and medium-sized businesses. The matrix of pairwise correlation coefficients is presented in Table 4.

Table 4. Matrix of paired correlation coefficients between the dynamics of the indicators of the recovery of entrepreneurial activity and inflation indices for the period from August 2020 to August 2021.

\begin{tabular}{|c|c|c|}
\hline & $\begin{array}{c}\text { Number of small and } \\
\text { medium-sized } \\
\text { enterprises }\end{array}$ & $\begin{array}{c}\text { Average number of employees } \\
\text { in small and medium-sized } \\
\text { enterprises }\end{array}$ \\
\hline Consumer price index & 0.5709 & -0.0382 \\
\hline Industrial Producer Price Index & 0.1206 & -0.2597 \\
\hline $\begin{array}{c}\text { Difference between consumer } \\
\text { price index and producer price } \\
\text { index for industrial goods }\end{array}$ & -0.0120 & -0.2664 \\
\hline
\end{tabular}

As noted above, the critical value of the modulus of the correlation coefficient in this case is 0.5529 . It should be noted that the consumer price index in the Russian economy differs significantly from the consumer price index. For example, in June 2021, the consumer price index was $100.74 \%$, and the producer price index for industrial goods was $102.30 \%$, which is significantly higher. At the same time, small and medium-sized businesses usually buy resources from large companies that have more market power. The individual small buyer is not important to them, and the demand for commodities has low price elasticity. 
At the same time, small and medium-sized enterprises are more likely to operate on the B2C model than B2B. This price difference can affect the restoration of entrepreneurial activity (although small and medium-sized enterprises do not always operate according to this model, they can buy something from the population and sell it to large companies or the state).

However, the data in Table 4 do not provide grounds for conclusions regarding the relationship between inflationary processes and the degree of recovery of entrepreneurial activity. Only the correlation coefficient between the consumer price index and the number of small and medium-sized enterprises (0.5709) is statistically significant. Nevertheless, it is hardly appropriate to conclude that an increase in the consumer price index contributes to the recovery of entrepreneurial activity, especially given the decline in real incomes of the population and the regional asymmetry in the development of entrepreneurship. It seems to the author that this is a statistical artifact.

The values of the remaining correlation coefficients are statistically insignificant. Price indices do not affect the dynamics of indicators reflecting the recovery of entrepreneurial activity. The difference in producer prices of industrial goods and the number of employees in small and medium-sized enterprises have a negative correlation coefficient, but its value is rather small.

It seems that the main factor affecting the level of recovery of entrepreneurial activity is the different level of regional economic development and the continuing concentration of business activity, factors of production in the Moscow agglomeration and some other centers. In addition, institutional factors are of great importance. In January 2021, the moratorium on the bankruptcy of legal entities and individual entrepreneurs working in the sectors most affected by the pandemic was lifted.

After that, the number of bankruptcy petitions to arbitration courts (initiated by both creditors and entrepreneurs themselves) increased sharply. The bankruptcy procedure from the filing of the application to the adoption of the ruling on the completion of the bankruptcy proceedings takes at least several months. Another 1-2 months are spent on sending by the arbitration court to the registering authority data on the removal of an organization or an individual entrepreneur from the register. At the same time, a significant number of bankruptcy procedures in Russia take more than six months.

Thus, a significant proportion of small and medium-sized enterprises in Russia were "zombie companies" that ceased operations, but were not officially excluded from the register of entrepreneurs due to the moratorium on bankruptcy. Since formally small and medium-sized enterprises were almost never removed from the register, while a certain number of new ones were registered, the impression was created that entrepreneurial activity was recovering. But many small and medium-sized businesses were only nominally reflected in their credentials.

The recovery in entrepreneurial activity, therefore, was largely illusory. This conclusion is in good agreement with the data on the decrease in the average number of employees in the field of small and medium-sized businesses. Small and medium-sized enterprises were forced to lay off their employees, but could not go through the liquidation procedure. From the beginning of 2021, the process of official deregistration of "zombie companies" began, which immediately showed that entrepreneurial activity had not recovered. At the same time, many bankruptcy procedures for small and medium-sized enterprises continue, which gives rise to negative forecasts.

\section{Conclusions}

The ability of small and medium-sized businesses to contribute to the achievement of sustainable development goals has been dramatically reduced by the novel coronavirus 
pandemic and the global economic crisis. An assessment of the degree of recovery of entrepreneurial activity in the Russian economy showed that the worst indicators of the number of small and medium-sized enterprises were observed in August 2020.

By August 2021, entrepreneurial activity formally recovered to the pre-crisis level, but there was a sharp decline in June-July 2021. The dynamics of the number of small enterprises is adequately described by a second-order polynomial, which indicates a reversal of the processes of recovery of entrepreneurial activity. At the same time, the assessment of the autocorrelation and heteroscedasticity of the models showed that this was influenced not by internal regularities, but by external shocks.

At the same time, the number of personnel in small and medium-sized enterprises monotonously decreased, in no way correlating with the number of small and medium-sized enterprises, which is somewhat paradoxical. In small and medium-sized businesses, almost 900 thousand jobs were lost, although it is precisely this, according to theoretical concepts, that should provide employment.

The study considered several hypotheses and explanations for this situation. Regional analysis showed that the varying degrees of severity of the new epidemiological restrictions introduced in the summer of 2021 did not explain the differences in the growth in the number of small and medium-sized enterprises. Moscow, Moscow region, St. Petersburg were able to increase the level of entrepreneurial activity, although there were the most serious restrictions. Most of the federal districts, in which soft, largely nominal, restrictions were introduced, showed a drop in the number of small and medium-sized enterprises. The relationship between entrepreneurial activity and inflation was not found either.

The explanation for the dynamics of entrepreneurial activity is the lifting of the moratorium on bankruptcy in the winter of 2021. Many small and medium-sized enterprises actually ceased their activities, but this was not formalized. In February 2021, many bankruptcy procedures started in masse, some of which ended in July-August. This also explains the lack of correlation between the number of small and medium-sized enterprises and the number of their employees. The layoffs were not accompanied by formal liquidation of firms.

The recovery of entrepreneurial activity, therefore, practically did not occur in the Russian economy; it is of a formal nature. It seems that in the coming months the number of small and medium-sized enterprises will decrease to a level lower than in August 2020. This is explained not only by the effect of epidemiological restrictions, but also by the difficult economic situation, in particular, by the decline in real incomes of the population.

The current situation complicates the achievement of sustainable development goals. Small and medium-sized enterprises cannot create jobs, prevent poverty and unemployment, and mitigate the effects of the economic downturn. There are several tools to change the situation. First, given the consequences of the crisis, it is necessary to significantly expand support for entrepreneurship; the country has financial resources for this. Second, to pursue structural and antitrust policies that reduce the bargaining power of large companies, their ability to unfairly take profits from small businesses. Thirdly, it is necessary to develop new competencies, work practices, business models of small and medium-sized businesses that can increase their competitiveness and survival. All this will allow the formation of stronger and more stable small and medium-sized enterprises capable of increasing the stability of the Russian economy.

\section{References}

1. J. Hall, M. Wagner, Journal of Small Business \& Entrepreneurship, 25 (4) (2012)

2. J. Hall, G. Daneke, M. Lenox, Journal of Business Venturing, 25 (5) (2009) 
3. M. Johnson, S. Schaltegger, Entrepreneurship Theory and Practice, 44 (6) (2020)

4. M. Filser, S. Kraus, N. Roig-Tierno, N. Kailer, U. Fischer, Sustainability, 11 (16) (2019)

5. G. M. Silva, P. J. Gomes, H. Carvalho, V. Geraldes, Business Strategy and the Environment, 30 (6) (2021)

6. A. Esteves, A. Genus, T. Henfrey, G. Penha-Lopes, M. East, Business Strategy and the Environment, 30 (3) (2021)

7. O. Omiunu, Handbook of Research on Small and Medium Enterprises in Developing Countries, 25 (1) (2017)

8. C. Pomare, Contemporary Issues in Entrepreneurship Research, 8 (2018).

9. A. Bartik, M. Bertrand, Z. Cullen, E. Glaeser, M. Luca, C. Stanton, Proceedings of the National Academy of Sciences, 117 (30) (2020)

10. M. Koren, R. Peto, PLoS ONE, 15 (9) (2020)

11. Q. Wang, W. Kang, Geographical Review, 111 (4) (2021)

12. S. Rashid, V. Ratten, World Journal of Entrepreneurship, Management and Sustainable Development, 173 (2021)

13. V. Nwokocha, O. Anyanwu, I. Madu, C. Nwankwo, SAGE Open, 11 (2) (2021)

14. V. Ratten, Strategic Change, 30 (2) (2021). 